\title{
Effect of Organic and Inorganic Nutrient Sources on Physical and Chemical Properties of Soil
}

\author{
Upendra Singh ", Arun A. David and Usha Sharma \\ Department of Soil Science, Sam Higginbottom Institute of Agriculture, Technology \& Sciences \\ (Deemed-to-be-University), Allahabad, 211007 U. P., India \\ *Corresponding author \\ A B S T R A C T \\ Keywords \\ Soil properties, \\ Nitrogen, \\ Phosphorus, \\ Potassium, Soil. \\ Article Info \\ Accepted: \\ 14 September 2017 \\ Available Online: \\ 10 October 2017 \\ A field experiment was conducted during rabi season 2014-15 at the \\ research farm of soil science, Allahabad School of Agriculture, laid out in \\ randomized block design on sandy loam soil, containing sand $65.14 \%$, silt \\ $21.12 \%$, and clay $13.74 \%$ (Inceptisols). It was observed that for post- \\ harvest soil properties in treatment $\mathrm{N}_{80} \mathrm{P}_{60} \mathrm{~K}_{40}+$ vermicompost @ $10 \mathrm{t} \mathrm{ha}^{-1}$ \\ were improved significantly due to organic and inorganic use of inputs. \\ Organic carban $0.67 \%$, available nitrogen $309.83 \mathrm{~kg} \mathrm{ha}^{-1}$, phosphorus 28.98 \\ $\mathrm{kg} \mathrm{ha}^{-1}$, potassium $188.11 \mathrm{~kg} \mathrm{ha}^{-1}$, pore space $50.14 \%$, $\mathrm{pH} 7.17$ were found \\ to be significant and bulk density $1.22 \mathrm{Mgm}^{-3}$, particle density $2.31 \mathrm{Mgm}^{-3}$, \\ EC at $0.24 \mathrm{dSm}^{-1}$ were found to be non-significantly improved in this \\ treatment.
}

\section{Introduction}

India is one among the leading oil seed producing countries in the world. Oilseeds form the second largest agricultural commodity after cereals. Mustard is the second important edible oil seed crop after groundnut. It plays an important role in the oil seed economy of the country. Indian mustard (Brassica juncea L.) commonly known as raya, rai or lahi is an important oilseed crop among the Brassica group of oilseed in India. It possesses a higher potential of production per unit area than other members of the family Cruciferae. Rape seed and mustard crops are being cultivated in 53 countries spreading over the six continents across the globe covering an area of 24.2 million hectare. Indians contribution to world and production is 28.3 and 19.8 percent respectively. In India, Toria is cultivated on 6.86 million hectares in Rabi season (Anonymous, 2011). Brassica juncea (L.) required cool and moist climate of winter months is the major factor for luxuriant growth and productivity of mustard in these states. The plant reaches about 4-5 feet in height and bears golden yellow coloures flowers. Its tiny, round seeds measuring about $1 \mathrm{~mm}$ in diameter is encased inside a fruit pod in a similar fashion like green pea pod. Mustard seeds are known by different names 
in different places - Sarson, rai or raya, toria or laha (Singh, 2012). Rapeseed-mustard is an important group of edible oil seed crops and contributes around $26.1 \%$ of the total oil seed production. Out of 57856 thousand tonnes of rapeseed-mustard seed produced over 30308 thousand ha in the world, India produce 5833 thousand tonnes from 5750 thousand $\mathrm{ha}^{-1}$. Indian mustard [Brassica juncea (L.)] contributes about $85 \%$ of the total rapeseedmustard produced in India (Krishna et al., 2005). Rapeseed-mustard is rich in minerals like calcium, manganese, copper, iron, selenium, zinc, vitamin A, B, C and proteins. $100 \mathrm{~g}$ mustard seed contains $508 \mathrm{kcal}$ energy, $28.09 \mathrm{~g}$ carbohydrates, $26.08 \mathrm{~g}$ proteins, 26.08 $\mathrm{g}$ total fat and $12.2 \mathrm{~g}$ dietary fiber (USDA, 2014). The oil and protein of Toria seeds of range from 40 to $48 \%$ and 20 to $40 \%$, respectively. The Toria seeds and oil are used as a condiment in preparation of pickles and for flavoring curries and vegetables. The leaves of young plant are used as green vegetable. It is also used for making, medicine, soaps and various lubricants, such as grease. Toria oil contains more of sulphur compounds. In Uttar Pradesh (Toria crop) was grown on an area of 0.64 million hectare with production of 0.53 million tonnes and the productivity of $831 \mathrm{~kg} \mathrm{ha}^{-1}$ (Anonymous, 2011).

Nitrogen is the most important nutrient, which determines the growth of the Toria crop and increases the amount of protein, methionine dry matter and the yield. Phosphorus and Potash are known to be efficiently utilized in the presence of Nitrogen. It promotes flowering, setting of siliqua and in increase the size of siliqua and yield. Phosphorus is an element for Toria and mustard. Phosphorus is generally deficient in majority of our Indian soils and need much attention for maintenance of soil fertility. When Phosphorus was applied in conjunction with Nitrogen and Potash, there was significant increase in the yield of Toria and mustard. Potassium is one of the seventeen elements which are essential for growth and development of plants. Mustard is an important oil seed crop of arid and semi-arid region. Potassium is required for improving the yield and quality of different crops because of its effect on photosynthesis, water use efficiency and plant tolerance to diseases, drought and cold as well for making the balance between protein and carbohydrates (Singh, 2012). One of the most important organic nutrient sources as Vermicompost is a composting process aided by earthworm can consume practically all kinds of organic matter. Vermicompost stores essential plant nutrient and it s nutrient absorbed by plant. It improves physical - chemical properties of soil such as soil porosity, water holding capacity, soil structure, soil aggregation, slow relies of nutrients, permeability, increase in cation exchange capacity, stimulation of soil flora and fauna etc. The composition of Vermicompost is $1.8 \% \mathrm{~N}, 2.0 \% \mathrm{P}$ and $1.6 \% \mathrm{~K}$ (Pawar 2007).

\section{Materials and Methods}

The Experiment was conducted during rabi season 2014-2015 on crop research farm of department of Soil Science, Allahabad School of Agriculture, Allahabad, (U.P.) India. The area is situated on the south of Allahabad on the right side of the river Yamuna on the south of Rewa road at a distance of about 6 $\mathrm{Km}$ from Allahabad city. It is situated at $25^{\circ} 24$ ' 23 " N latitude, $81^{\circ} 50$ ' $38^{\prime \prime}$ E longitude and at the altitude of 98 meter above the sea level.

The treatments consisted of nine combination of organic and inorganic source of fertilizers $\left.\begin{array}{llllllll}\mathrm{T}_{0} & \left(\mathrm{~L}_{0}\right. & \mathrm{V}_{0}\end{array}\right)$ control, $\mathrm{T}_{1} \quad\left(\begin{array}{llll}\mathrm{N}_{0} & \mathrm{P}_{0} & \mathrm{~K}_{0} & +\end{array}\right.$ Vermicompost@ $@ \mathrm{t} \mathrm{ha}^{-1}, \mathrm{~T}_{2}\left(\mathrm{~N}_{0} \mathrm{P}_{0} \mathrm{~K}_{0}+\right.$ Vermicompost @ $10 \mathrm{t} \mathrm{ha}^{-1}, \mathrm{~T}_{3}\left(\mathrm{~N}_{40} \mathrm{P}_{30} \mathrm{~K}_{20}+\right.$ Vermicompost ${ }_{0}, \quad \mathrm{~T}_{4} \quad\left(\begin{array}{lllll}\mathrm{N}_{40} & \mathrm{P}_{30} & \mathrm{~K}_{20} & +\end{array}\right.$ 
Vermicompost@ $9 \mathrm{t} \mathrm{ha}^{-1}, \mathrm{~T}_{5}\left(\mathrm{~N}_{40} \mathrm{P}_{30} \mathrm{~K}_{20}+\right.$ Vermicompost@10 t ha ${ }^{-1}, \mathrm{~T}_{6}\left(\mathrm{~N}_{80} \mathrm{P}_{60} \mathrm{~K}_{40}+\right.$ $\begin{array}{llllll}\text { Vermicompost } & 0, & \mathrm{~T}_{7} & \left(\mathrm{~N}_{80}\right. & \mathrm{P}_{60} & \mathrm{~K}_{40}+\end{array}$ Vermicompost@ $5 \mathrm{t} \mathrm{ha}^{-1}, \mathrm{~T}_{8}\left(\mathrm{~N}_{80} \mathrm{P}_{60} \mathrm{~K}_{40}+\right.$ Vermicompost@10 $\mathrm{tha}^{-1}$. The trial was laid out in a randomized block design with three replication, plot size was $2 \times 2 \mathrm{~m}$ for crop seed rate is $15-20 \mathrm{~kg} \mathrm{ha}^{-1}$ (Brassica juncea L.) Cv. Kranti. Mustard grows in $13^{\text {th }}$ November 2014 and the source of nitrogen, phosphorus, and potassium, were Urea, SSP, MOP, respectively. Basal dose of fertilizer was applied in respective plots according to treatment allocation unifurrows opened by about $5 \mathrm{~cm}$. All the agronomic practices were carried out uniformly to raise the crop. The crop was harvested on $10^{\text {th }}$ March. Soil samples were collected from the soil $0-15 \mathrm{~cm}$ depth, air dried kept in an oven at $105^{\circ} \mathrm{C}$ for $48 \mathrm{hrs}$ for drying, pass through $2 \mathrm{~mm}$ sieve, soils were analysis by using standard procedures as described for $\mathrm{pH}$ 1:2 (w/v) (Jakson 1958), EC (dSm $\left.{ }^{-1}\right)$ (Wilcox 1950), organic carban (\%) (Walkley and Black
1947), available nitrogen $\mathrm{kg} \mathrm{ha}^{-1}$ (Subbiah and Asija 1956), phosphorus $\mathrm{kg} \mathrm{ha}^{-1}$ (Olsen et al., 1954) and potassium $\mathrm{kg} \mathrm{ha}^{-1}$ (Toth and Price 1949). The physical and chemical properties at start of experiment are presented in Tables 1 and 2, respectively.

\section{Results and Discussion}

\section{Physical properties of soil (post-harvest)}

The results in given Table 3 indicate some of the important parameter on physical properties on mustard crop. Organic and inorganic fertilizers conjunction on bulk density and particle density to be nonsignificant and on pore space to be significant. The bulk density $\left(\mathrm{Mgm}^{-3}\right)$, particle density $\left(\mathrm{Mgm}^{-3}\right)$ and pore space $(\%)$ of postharvest soil was recorded 1.22, 2.31 and 50.14 with the treatment $T_{8}$ respectively. The slight decreased in bulk density, particle density and pore space may be due to tillage operation and increase in plant growth.

Table.1 Physical properties of soil (pre- sowing)

\begin{tabular}{lll}
\hline Particulars & Results & Method employed \\
\hline Sand (\%) & 65.14 & Bouyoucous hydrometer (1952) \\
Silt (\%) & 21.12 & \\
Clay (\%) & 13.74 & \\
Texture class & Sandy loam & \\
Bulk density $\mathrm{Mgm}^{-3}$ & 1.47 & Graduated measuring cylindrical (Black 1965) \\
Particle density $\mathrm{Mgm}^{-3}$ & 2.52 & Graduated measuring cylindrical (Black 1965) \\
Pore space $(\%)$ & 51.68 & Graduated measuring cylindrical (Black 1965) \\
Soil EC $\left(\mathrm{dSm}^{-1}\right)$ at $27^{0} \mathrm{C}$ of 1:2 soil & 0.26 & Digital conductivity meter (Wilcox 1950) \\
$\begin{array}{l}\text { Water suspension } \\
\text { Soil pH }(1: 2) \text { soil water suspension } \\
\text { (w/v) }\end{array}$ & 7.69 & Digital pH meter (Jackson 1958) \\
\hline
\end{tabular}

Table.2 Chemical properties of soil (pre- sowing)

\begin{tabular}{lll}
\hline Particulars & Results & Method employed \\
\hline Organic carbon & 0.38 & Rapid titration method (Walkley and Black 1947) \\
Available nitrogen $\left(\mathrm{kg} \mathrm{ha}^{-1}\right)$ & 221.81 & Alkaline permanganate method (Subbiah and Asija 1956) \\
Available Phosphorus $\left(\mathrm{kg} \mathrm{ha}^{-1}\right)$ & 20.55 & Colorimetric method (Olsen et al., 1954) \\
Available Potassium $\left(\mathrm{kg} \mathrm{ha}^{-1}\right)$ & 121.01 & Flam photometric method (Toth and Price, 1949) \\
\hline
\end{tabular}


Table.3 Effect of different levels of organic and inorganic nutrient sources on physical and chemical properties after harvest mustard crop

\begin{tabular}{|c|c|c|c|c|c|c|c|c|c|}
\hline $\begin{array}{l}\text { Treatment } \\
\text { combination }\end{array}$ & $\begin{array}{l}\text { Bd } \\
\left(\mathrm{gcm}^{3}\right)\end{array}$ & $\begin{array}{l}\text { Pd } \\
(\mathrm{gcm})\end{array}$ & $\begin{array}{l}\text { Pore space } \\
(\%)\end{array}$ & $\begin{array}{l}\text { pH } \\
(1: 2 \mathrm{w} / \mathrm{v})\end{array}$ & $\begin{array}{l}\text { EC } \\
\left(\mathrm{dSm}^{-1}\right)\end{array}$ & $\begin{array}{l}\mathrm{N} \\
\left(\mathrm{kg} \mathrm{ha}^{-1}\right)\end{array}$ & $\begin{array}{l}\mathrm{P}_{2} \mathrm{O}_{5} \\
\left(\mathrm{~kg} \mathrm{ha}^{-1}\right)\end{array}$ & $\begin{array}{l}\mathrm{K}_{2} \mathrm{O} \\
\left(\mathrm{kgha}^{-1}\right)\end{array}$ & $\begin{array}{l}\text { Organic } \\
\text { Carbon }(\%)\end{array}$ \\
\hline $\mathbf{T}_{0}=\mathrm{L}_{0} \mathrm{~V}_{0}$ & 1.33 & 2.73 & 46.81 & 7.77 & 0.19 & 261.96 & 21.99 & 135.79 & 0.42 \\
\hline $\mathrm{T}_{1}=\mathrm{L}_{0} \mathrm{~V}_{1}$ & 1.28 & 2.62 & 46.81 & 7.44 & 0.20 & 281.88 & 22.89 & 154.93 & 0.48 \\
\hline$T_{2}=L_{0} V_{2}$ & 1.25 & 2.41 & 50.01 & 7.37 & 0.20 & 295.50 & 26.28 & 167.15 & 0.53 \\
\hline $\mathbf{T}_{3}=\mathbf{L}_{1} \mathbf{V}_{0}$ & 1.30 & 2.41 & 46.94 & 7.47 & 0.20 & 270.35 & 22.89 & 145.00 & 0.44 \\
\hline $\mathbf{T}_{4}=\mathbf{L}_{1} \mathbf{V}_{1}$ & 1.31 & 2.52 & 46.81 & 7.43 & 0.21 & 291.31 & 25.38 & 161.12 & 0.51 \\
\hline $\mathbf{T}_{5}=\mathrm{L}_{1} \mathbf{V}_{2}$ & 1.23 & 2.62 & 50.14 & 7.27 & 0.23 & 304.93 & 28.08 & 180.62 & 0.62 \\
\hline $\mathbf{T}_{6}=\mathrm{L}_{2} \mathrm{~V}_{0}$ & 1.28 & 2.33 & 44.72 & 7.50 & 0.22 & 276.64 & 23.79 & 148.93 & 0.46 \\
\hline $\mathbf{T}_{7}=\mathbf{L}_{2} \mathbf{V}_{1}$ & 1.25 & 2.31 & 50.01 & 7.20 & 0.23 & 300.74 & 27.18 & 175.62 & 0.56 \\
\hline $\mathbf{T}_{8}=\mathrm{L}_{2} \mathbf{V}_{2}$ & 1.22 & 2.31 & 50.14 & 7.17 & 0.24 & 309.83 & 28.98 & 188.11 & 0.67 \\
\hline Mean & 1.27 & 2.47 & 48.04 & 7.40 & 0.21 & 288.12 & 25.45 & 161.91 & 0.52 \\
\hline C.D.at 5\% & 0.13 & 0.35 & 8.78 & 0.25 & 0.013 & 5.18 & 0.74 & 4.71 & 0.05 \\
\hline
\end{tabular}

\section{Chemical properties of soil (post-harvest)}

The results in given Table 3 indicate some of the important parameter on physical properties on mustard crop. Organic and inorganic fertilizers in conjunction on EC was found non-significant and $\mathrm{pH}$, Organic carban (\%), available nitrogen $\left(\mathrm{kg} \mathrm{ha}^{-1}\right)$, available phosphorus $\left(\mathrm{kg} \mathrm{ha}^{-1}\right)$, available potassium $(\mathrm{kg}$ $\left.\mathrm{ha}^{-1}\right)$ was found significant. EC $\left(\mathrm{dSm}^{-1}\right)$, Organic carban $(\%)$, available nitrogen $\left(\mathrm{kg} \mathrm{ha}^{-1}\right)$, available phosphorus $\left(\mathrm{kg} \mathrm{ha}^{-1}\right)$, available potassium $\left(\mathrm{kg} \mathrm{ha}^{-1}\right)$ was recorded $0.24,0.67,309.83,28.98,188.11$ respectively in the treatment $\mathrm{T}_{8}$ that was significantly higher as compared to other treatment combination.

$\mathrm{pH}$ was recorded 7.17 in the treatment $\mathrm{T}_{8}$ that were significantly lower as compared to other treatment combination. The slight decreased in soil $\mathrm{pH}$ and increased in soil EC $\left(\mathrm{dSm}^{-1}\right)$, Organic carban (\%), available nitrogen $\left(\mathrm{kg} \mathrm{ha}{ }^{-1}\right)$, available phosphorus $\left(\mathrm{kg} \mathrm{ha}^{-1}\right)$, available potassium $\left(\mathrm{kg} \mathrm{ha}^{-1}\right)$ may be due to increase in levels of organic and inorganic fertilizer and plant growth, which is turn increased the plant residues into soil.
It may be concluded from trial that the various level of NPK, and Vermicompost used from different sources in the experiment, the treatment combination $\mathrm{T}_{8}\left(\mathrm{~N}_{80} \mathrm{P}_{60} \mathrm{~K}_{40} \mathrm{Kg}\right.$ $\mathrm{ha}^{-1}$, and vermicompost @ $10 \mathrm{t} \mathrm{ha}^{-1}$ ) was found to be the best, for improvement in physical and chemical properties of soil.

\section{Acknowledgements}

The authors are grateful to the Department of Soil Science, Allahabad School of Agriculture, for taking their keep interest and encouragement to carry out the the research work at Sam Higginbottom Institute of Agriculture, Technology \& Sciences Deemedto-be-University.

\section{References}

Anonymous, 2011. Ministry of Agricultural, Government of India.

Anonymous, 2011-12. Indian MART Inter Mesh Ltd.

Anonymous, 2014 USDA.

Bhattacharya, R., Vedprakash, Kundu, S., Srivastava, A.K. and Gupta, H.S. 2004. Effect of long term manuring on soil organic carbon, bulk density and water 
retention characteristics under soybean -wheat cropping sequence in northwestern Himalayas. Journal of the Indian society of soil science 52:238242.

Black, C.A., 1965. Methods of soil analysis. Vol. I.Am. Soc. Agron. Madison, Wisconsin, U.S.A.

Buoyoucos, G.J., 1927. The hydrometer as a new method for the mechanical analysis of soil. Soil sci., 23: 393-395.

Fisher, R. A., 1950. Technique of Analysis of Variance. Handbook of Agricultural Statistics. B-29-110.

Jackson, M. L., 1958. Soil chemical analysis, Prentice Hall, Inc, Englewood Cliffe, N.J.

Khin, S. A., 2011. Investigation on the Effectiveness of Zinc Sulphate and Biofertilizer on Mustard Plant. World Ac. of Sc. Eng. and Tec. 51

Krishna, S., Singh, R.S. and Bhushan, C. 2005. Effect of phosphorus, sulphur and zinc fertilization on quality of mustard (Brasslca juncea L.) Grown under semiarid conditions Ag. Sci. Digest. 25 (3): 198 - 200.

Olsen, S.R., Cole, C.V., Watnahe, F.S. and Dean, L.A. 1954. Estimation of available phosphorus in soils by extraction with sodium bicarbonate U.S. Deptt. Agr. Circ. 939.

Singh, C., Singh, P. and Rajbir, S. 2012. Oil crops of mustard (Brassica juncea L.) General introduction Modern techniques of raising field crops. Oxford \& IBH publishing Company Pvt. Ltd. New Delhi. Pp.273-291

Singh, J., Sahay, N., Singh, H. and Bhadauria, H.S. 2012. Nitrogen and sulphur requirement of mustard under different crop Sequences Ann. Pl. Soil Res. 14 (2): 113-115.

Subbiah, B.V., and Asija, C.L. 1956. Arapid procedure for the estimation of available nitrogen in soil current science. 25: 259-260

Toth, S.J., and A.L. Prince 1949. Estimation of Cation Exchange Capacity and exchangeable $\mathrm{Ca}, \mathrm{K}$ and $\mathrm{Na}$ content of soil by Flame Photometer technique. Soil Sci. 67: 439-445.

Walkey, A., and Black, I. A. 1947. Critical examination of rapid method for determining organic carbon in soils, effect of variance in digestion conditions and of inorganic soil constituents. Soil sci 632:251.

Wilcox, L.V., 1950. Electrical conductivity, Am water works Assoc. J. 42: pp 775776.

\section{How to cite this article:}

Upendra Singh, Arun A. David and Usha Sharma. 2017. Effect of Organic and Inorganic Nutrient Sources on Physical and Chemical Properties of Soil. Int.J.Curr.Microbiol.App.Sci. 6(10): 1374-1378. doi: https://doi.org/10.20546/ijcmas.2017.610.162 